\title{
The Development Prospects of Cross-border E-commerce in Thailand
}

\author{
Fang Liu \\ International Business School \\ Yunnan University of Finance and Economics \\ Kunming, China \\ Candy-9110@foxmail.com \\ Yuhui Feng* \\ International Business School \\ Yunnan University of Finance and Economics \\ Kunming, China \\ feng@ynufe.edu.cn \\ Wei Wang \\ International Business School
}

\author{
Yunnan University of Finance and \\ Kunming, China \\ 704234551@qq.com
}

\author{
Menglan Qiu \\ International Business School \\ Yunnan University of Finance and Economics \\ Kunming, China \\ 879579662@qq.com \\ Haiyang Yang \\ International Business School \\ Yunnan University of Finance and Economics \\ Kunming, China \\ 530882807@qq.com
}

\begin{abstract}
With the development of Internet technology, cross-border e-commerce has become a new trade industry in the world. It is an unstoppable trend to expand the cross-border e-commerce and increase trade among countries. Cross-border e-commerce in Thailand develops relatively late, but Thai authority also finds cross-border e-commerce as a huge development potential. In recent years, Thailand is actively promoting the development of e-commerce and cross-border e-commerce.
\end{abstract}

Keywords-Internet technology; Thailand; cross-border E-commerce; development

\section{INTRODUCTION}

In Thailand, cross-border e-commerce has become a new industrial model to accelerate economic development. At the end of the twentieth century, the Thai authorities and the business department set out a series of works to promote the development of cross-border e-commerce. Under the background of "One belt, one road", the research on Thai cross-border e-commerce is conducive to the better development of Thai economy. In recent years, Chinese cross-border e-commerce has developed rapidly and the scale of transaction continued to expand, contributing a higher proportion on value of import and export. The trading volume of Chinese cross-border e-commerce reached 6.3 trillion RMB in 2016, and the e-commerce between China and Thailand has also gradually developed. Thailand, as the logistics, trade and finance center of China-ASEAN under "One Belt, One Road", is geographically located in the heartland of the ASEAN region, connecting China and
ASEAN market, with an enormous development opportunities in cross-border e-commerce between China and Thailand. The continuous expansion of Sino-Thai trade, cross-border e-commerce plays more important role in business and trade between the two countries. At present, e-commerce in Chinese domestic market has entered into its saturation period, while it's an emerging market at initial development stage with a moderate competition between e-commerce platforms in Southeast Asia region. Cross-border e-commerce in Thailand develops relatively late, but Thai authority also finds cross-border e-commerce as a huge development potential. The e-commerce volume in Thailand raised $15 \%$ in 2016 , to 230 240 billion THB. Thailand is also actively promoting the development of e-commerce and cross-border e-commerce for the past few years.

Based on the relevant literature, this paper found that there were few researches on the cross-border e-commerce between China and Thailand and also there were some analysis on the development and problems of Sino-Thai cross-border e-commerce. The author used the opportunity of internship in Thailand to carry out a field survey and research on the transaction scale, trading platform, payment method, logistics and so on for cross-border e-commerce in Thailand from a local people's perspective. Meanwhile, the author designs a questionnaire for Thai consumers who are participating in cross-border online shopping in four aspects including personal basic information, personal online shopping situation, logistics and transport as well as cross-border online shopping services. Through a case study of Thai largest cross-border e-commerce platform - Lazada, this paper gives a brief 
introduction to Lazada and its operation status. In addition, the author's personally experiences shopping on Lazada. Through statistical analysis, the paper finds there are still some restricted factors in logistics, payment, laws and regulations, network infrastructure and other aspects in current development of Sino-Thai cross-border e-commerce, and that Sino-Thai cross-border e-commerce as a new commercial sector presents a huge opportunity which will continue to push the "One Belt, One Road". Basis on this, the author puts forward some suggestions on how to speed up the development of cross-border e-commerce between China and Thailand, which gives an enlightenment to relevant departments, enterprises and individuals on how to further expand Sino-Thai cross-border e-commerce.

\section{RELEVANT THEORETICAL BASIS}

In the study of factors affecting cross-border e-commerce, Shin[1] argued that electronic payment is an important part of cross-border e-commerce and can improve transaction convenience. In addition, Urciuoli[2] found that electronic customs clearance platform could facilitate business operations and save clearance costs by survey analysis of the World Customs Organization (WCO) annual meeting of the Council. Raus[3] and some researches also illustrate this point. Samiee[4], Zhongquan Zou[5], Nguyen[6] empirical studied and clarified the role of international logistics services throughout the cross-border e-commerce promotion with factor analysis.

Domestic Li Wen-feng[7] argued global supply chain operation model had been a core competency in international trade, further pointed that public service platform with international features and industry characteristics should be promoted by relevant industry organizations or trade associations. Yang Jian-zheng[8] summarized main factors from trading process perspective as follows: information acquisition, electronic customs, electronic payment, logistics and distribution. Jiao Chun-feng[9] emphasized that in order to promote e-commerce development, enterprises should improve informatization of international trade process containing multiple aspects of customs, banking, insurance, transportation, inspection, taxes, etc. Liu Juan's[10] study found that foreign trade information collection and electronic payment could no longer constrain the development of cross-border e-commerce trade, but customs clearance, logistics remains an obstacle to cross-border e-commerce development. Furthermore, China's E-commerce (2012) from Ministry of Commerce of the People' s Republic of China (2013), Li Ji-qi (2012), Cao Hong-feng (2007), Yang Jian-zheng (2008) put forward the corresponding countermeasures for cross-border e-commerce problem.

The research data on Thailand cross-border e-commerce currently collected through the existing public channels is not yet rich. From the size of Thai Internet users, e-commerce traction scale, e-commerce enterprise, e-commerce payment method, e-commerce logistics and other four aspects, Tan Yuping (2015) not only gave an overview of Thailand e-commerce industry, and talked about the Thai government which introduced policies and laws to support the development of Thailand e-commerce industry, but also put forward the existing problems when developing Thailand e-commerce industry, and learned the e-commerce development mode and the effective policies and laws from Singapore, Australia and Japan. Combined with the market situation, Ma Bingqiong (2015) made a classification survey on various types of Thai e-commerce B2C, B2B, B2G, and put forward four division methods about Thai e-commerce industry like the type of economic activities, the type of sales, the number of direct practitioners and the sales model of online and offline, which can make us know the general situation and development issues of e-commerce industry in Thailand, but there is no in-depth study of Thailand e-commerce major obstacles, so we need spend more time and effort to study and understand the development prospects of cross-border e-commerce in Thailand.

\section{OVERVIEW OF THE DEVELOPMENT OF CROSS-BORDER E-COMMERCE IN THAILAND}

E-commerce has been gaining momentum in Thailand, mostly thanks to the wider penetration of credit and debit cards, facilitating online payment. During the period of 2009-2014, the number of credit and debit cards in circulation increased from 45 million to 67 million. Mobile internet is also driving online spending; after China, Thailand has the largest number of mobile shoppers in the Asia Pacific region.

\section{A. Transaction size}

According to the survey of Electronic Transactions Development Agency (ETDA), the total value of e-commerce market in Thailand was 369.726 billion yuan (about 2 trillion baht) in 2014, with the predominance of B2B mode which accounting for $74.65 \%$ of the e-commerce market; B2C mode and $\mathrm{B} 2 \mathrm{G}$ mode are separately in the proportion of $24.90 \%$ and $0.45 \%$. The value market of e-commerce in Thailand in 2015 has reached 400 billion yuan (about 2.2 trillion baht), with year-on-year growth of $10.41 \%$, which is expected to increase $12.42 \%$ in 2016. Within it, B2B mode, B2C mode and B2G mode are respectively with year-on-year growth of $8.15 \%$, $23.87 \%$ and $3.30 \%$. According to the study in 2016 conducted by PayPal and market research firm of Ipsos, the number of e-commerce consumers in Thailand in 2016 reached 7.9 million, who purchased 2 million products from foreign websites. The average cross-border online shopping expenditure of Thai consumers was 30893 baht, the average e-commerce shopping spending was 41215 baht.

You can see that the e-commerce market in Thailand has grown a lot, but there is still a big gap of total value market between e-commerce and traditional marketing, that is, e-commerce is less than $1 \%$ of the total value of traditional marketing market. That means Thailand e-commerce market has great potential for growth, and with the help of continuous expansion of $4 \mathrm{G}$ network services and smart phone penetration, cross-border e-commerce in Thailand will usher in a new development opportunities.

\section{B. E-commerce Trading Platform}

Thai e-commerce business platform can be divided into five categories: B2C business platform, B2B2C business platform, $\mathrm{C} 2 \mathrm{C}$ business platform, group-buying platform and parity platform. As Thailand didn' $t$ create a cross-border 
e-commerce platform which can directly do business with foreigners, bilateral cross-border e-commerce transactions are mainly be achieved through the international cross-border e-commerce platform.

At present, in most situations, e-commerce development in Thailand is not to be guided by professional e-commerce platform, but achieves e-commerce transactions (B2C, C2C) through the social platform, like Facebook mode, Instagram mode, social communication APP mode. In Facebook, Instagram, Line and other social platforms, Thailand people are concerned about small businesses which have no physical store but a wide range of goods. In 2015, among 500,000 online sellers in Thailand, 10515 stores are on Facebook and 11213 stores are on Instagram.

\section{Payment Method}

Online payment is not the mainstream payment method in Thailand. Currently, there are six major payment methods. The first is for the prepaid card such as True Money cash card, and these prepaid cards can be bought in 7-11 and Tesco Lotus, which accounting for $80 \%$ of payment market. The second is for the operator billing, such as the mainstream mobile phone payment service providers in Thailand are Easy2pay, JMT and so on, which mainly rely on the three major operators (AIS, DTAC, True move) for short-term billing, this rely on telecom operators to do traffic charges. The third and fourth is paid by Internet banking and ATM, which occupy a smaller proportion of payment market. Generally, Thailand people accepted Internet bank are not high, who question its security, and because low penetration rate of ATM, ATM didn' t get effective popularization. The sixth is online (such as PAYSBUY third party payment) and mobile wallet, including M-True money wallet and so on. Mainstream payment of online shopping in Thailand is more primitive, and they even prefer cash on delivery, directly save the process of online payment, but cash on delivery can not be used for cross-border e-commerce payment.

\section{Logistics Transportation}

Logistics system in Thailand is relatively backward. Postal logistics company basically occupied a majority market, most cross-border online shopping goods are transported by post, only some private businesses and individuals may use UPS, DHL, Fedex and other logistics to transport goods. Using EMS to transport goods can make consumers know the logistics process so that prevent the loss of goods in the transport process, which is conducive to strengthening the trust of consumers on the logistics, but it will lead to an increase in logistics costs. But assuming that businesses use surface mail, which will often encounter such situations like the loss of goods, longer transport time, etc., it will lead to the emergence of logistics security problems. There are also many problems needed to be solved in the Thai Post, such as violent transport, slow delivery, and management to be improved, so the cost is relatively high.

\section{INVESTIGATION AND ANALYSIS OF CROSS-BORDER E-COMMERCE IN THAILAND}

The survey was conducted on the basis of a three-month internship at Rangsit University in Thailand. Through the investigation of Thai people on the application of Thailand cross-border e-commerce, we have known the current situation of Thai people who participated in cross-border online shopping, and the prospects of cross-border e-commerce.

In Thailand, 21-30 year-old group is the main online shopping consumers, more than $90 \%$ people have had online shopping experience, but only about $52 \%$ people are involved in cross-border online shopping. More people are used to the use mobile devices to access the Internet. Consumers generally carry out cross-border online shopping through Lazada, Amazon and Weloveshopping platform for clothing, bags, shoes and cosmetics. Affordable is the most important reason for Thailand consumers to participate in cross-border transactions. Most people still pay with e-banking / ATM and credit card. But because of the complexity of payment security in Thailand, unstable payment environment, the user's habit, etc, hacker attacks and information stolen events often happened, so online payment still has a long way to go. Now, most consumers don' $t$ trust online payment of bank and credit card penetration is very low, in 2014 , only $5.5 \%$ people have credit cards. The restrictions on online payments are not conducive to the development of Thailand cross-border e-commerce transactions.

Fear of defective products or fakes (58\%), lack of confidence on online payment security $(46.4 \%)$, slow logistics services $(42 \%)$ are the main reasons why many consumers do not conduct cross-border online shopping. There are many constraints in the development of cross-border e-commerce in Thailand, such as non-guaranteed product quality, unsafe online payment, high logistics cost, bad logistics service, slow delivery, restrictions on policies and regulations and so on. So as high as $73.9 \%$ people think that in the development of cross-border e-commerce, the relevant laws need be improved to protect the legitimate interests of buyers and sellers. Some people think perfecting logistics quality (59.4\%) and simplifying shopping process $(30.4 \%)$ are conducive to improving the development of cross-border e-commerce. But meanwhile, up to $50.7 \%$ consumers feel cross-border e-commerce has great development prospects, which will become the trend of online shopping; no one think it will be bleak. That shows although the development of cross-border e-commerce in Thailand just starts and has many shortcomings, Thailand consumers have sufficient confidence on the development of cross-border e-commerce.

Taking advantage of having an internship in Thailand, from a Thai perspective, we can have a deeper understanding of the development of cross-border e-commerce. It develops late, but maintains a rising trend. However, there are still some problems affecting its development, such as logistics, payment security, network infrastructure, product quality and other issues have not yet been fully resolved, and laws and regulations about cross-border e-commerce still need be improved. But it is also a huge development opportunity. Utilizing "One Belt, One Road" development strategy, Thailand government can improve its infrastructure by working with China, promote trade facilitation, develop and optimize trade structure, and improve logistics, communication, law, insurance, finance and etc. to promote 
the development of e-commerce and cross-border e-commerce in Thailand.

\section{DeVElopment PROSPECTS}

Key findings from a publication suggest that, following Indonesia, Thailand contains the second biggest economy in the Southeast Asia region, and also ranks second in E-Commerce sales. The expansion of E-Commerce in Thailand is furthered due to improved Internet penetration, with nearly half of the population having Internet access in 2016. While E-Commerce penetration still consists of single digits, the rate of $\mathrm{B} 2 \mathrm{C}$ E-Commerce sales is forecast to blossom in the upcoming years.

ETDA shows Thailand e-commerce total transactions is more than 2.52 trillion baht in 2016, accounting for $40 \%$ of total domestic retail and services. E-commerce and cross-border e-commerce trading volume are increasing year by year. With the rapid development of online sales and payment systems, the current growth rate of Thailand customers' cross-border sales is much faster than the overall e-commerce market, which includes B2B and B2C.

\section{A. The Rapid Development of Mobile Internet}

Mobile Internet becomes an primary trend of future development of Thailand cross-border e-commerce. Now more and more 4G and other mobile phone network users joined the mobile Internet army. The increase of $4 \mathrm{G}$ service users and the improvement of transaction security increase online trading activities so that the scale of e-commerce sales will rise sharply, so in the future development of Thailand cross-border e-commerce, the demand for cross-border e-commerce for mobile Internet users will be growing.

Information from a report reveals that the key market trends in Thailand are mobile and social commerce. Smartphones have linked people to the Internet, leaving the smartphone penetration rate almost the same as the Internet and making smartphones a leading device used to access the Internet. Thailand leads the region in share of E-Commerce consumers buying via mobile. M-Commerce sales are forecast to reach a share of close to half of total E-Commerce spending in the upcoming years. Furthermore, social media has become an important sales platform for retailers in Thailand, with over half of online costumers ordering via social networks.

\section{B. Internationalization of E-commerce becoming more and more obvious}

Nowadays, e-commerce in Southeast Asia and the rest of the world is extending to reach around the world, such as Qoo 10 (China) through the network sold its products to Singapore, Malaysia and Indonesia, which expected to arrive in Thailand soon; Alibaba also began to reach Southeast Asia countries like Thailand; Thailand tax-free group King Power officially entered Chinese market through cross-border e-commerce. It shows that e-commerce is moving towards internationalization. Meanwhile, Lazada has placed as the top online marketplace in Thailand due to its Thai website receiving more visits than the closest two contenders combined. In an effort to challenge Lazada, another major player, the Central Group, acquired Zalora, an online clothing retailer while also planning to increase omnichannel development and logistics capabilities during 2017. Launched in December 2016, South Korea's 11 street also made its mark by registering thousands of sellers and over one hundred thousand consumers on its platform by early 2017 .

Cross-border e-commerce consumers in Thailand often buy these categories of products: fashion, digital entertainment, education and consumer electronics.

\section{A. Personalized Promotion and Marketing}

Now, Network marketing gets more and more attention and develops rapidly, selecting personalized way to promote network marketing will become more important, and targeted promotion program is good for doing network marketing.

Compared with other countries in Southeast Asia, Thailand e-commerce market has evident advantage, its number of operators, marketing methods and consumer behavior preferences are all in the lead. Meanwhile, Thailand government implements digital economic strategy, committed to the development of infrastructure, and modifies the law, and mobile communications market develop fast, which are both promote the development of cross-border e-commerce market.

\section{Strengthening Macro-planning and Guidance on Cross-border E-commerce by Government}

In recent years, in accordance with the development requirements of market economy and network economy, the United States and China have increased the government's support for the development of e-commerce, so the Thai government should encourage the development of cross-border e-commerce. Government plays an important role in promoting the expansion of e-commerce. Therefore, it is necessary to formulate relevant policies to protect and develop e-commerce, and to have a detailed division of work to truly implement them. The development goal of supporting e-commerce into the community is to increase market sales, which can through $\mathrm{B} 2 \mathrm{~B}$ and $\mathrm{B} 2 \mathrm{C}$ and other forms of marketing to enhance sales skills. Every year the government should have financial support with no less than $20 \%$ to develop and promote the expansion of e-commerce.

According to ETDA survey, it is very urgent to get the support of government for the development of cross-border e-commerce in Thailand. Firstly, government can improve the transport system to reduce the cost of transport; Secondly, the support of government public relations can help solve the problems encountered in cross-border e-commerce; Thirdly, government can establish security for consumers to protect the safety when shopping online and so on.

The Thai government should take the country as the center of e-commerce to get domestic business operators together through international trade finance and international exchange. At the same time, it should encourage private sector to learn business knowledge and business operations. Moreover, government should establish e-commerce consulting department for counseling entrepreneurs and formulate relevant policies for stimulating economic development.

All in all, cross-border e-commerce in Thailand is in the early stage of development, compared to other countries in 
Southeast Asia, the factors that affecting the development of cross-border e-commerce like the Internet, mobile hardware environment, consumer online shopping ability and popularity and purchasing power in Thailand are in a relatively leading position, which has a huge development potential. And, under the strategic background of "One Belt, One Road", Thailand government is actively working on promoting the development of cross-border e-commerce and cross-border e-commerce in Thailand has great developing future, so we should catch this opportunity to speed up the development of cross-border e-commerce between China and Thailand.

\section{ACKNOWLEDGMENT}

In this paper, I want to thank my Professor, Yuhui Feng, who gives me much advice in the process of my writing paper. I would also like to thank Professor Shake Feng and Professor Hong Yi, who help me choose my paper title and thought-provoking suggestions on writing. Here, I want to express my deep gratitude and blessing to all of you.

\section{REFERENCES}

[1] Soonduck Yoo; Seung-jung Shin; Dae-hyun Ryu, "The Supplier Management and Approval in Reverse Trade Card: An Electronic Payment System on the B2B," Ubiquitous Information Technologies and Applications (CUTE), 2010 Proceedings of the 5th International Conference on, vol., no., pp. 1,6, 16-18 Dec. 2010.

[2] Luca Urciuoli, Juha Hintsa, Juha Ahokas, Drivers and barriers affecting usage of e-Customs - A global survey with customs administrations using multivariate analysis techniques, Government Information Quarterly, Available online 29 September 2013.

[3] R.Marta, F. Barbara, and B. Roman, "Electronic customs innovation: An improvement of governmental infrastructures," Government Information Quarterly, vol. 26, pp. 246-256, April 2009.
[4] Saeed Samiee, Global marketing effectiveness via alliances and electronic commerce in business-to-business markets, Industrial Marketing Management, vol. 37, pp. 3-8, January 2008.

[5] Z.Q. Zou, "The Study on Electronic Commerce and Development of International Logistics," Electronic Commerce and Security, 2008 International Symposium on, vol., no., pp. 704-707, 3-5, Auguestc 2008.

[6] H.O. Nguyen, "Critical factors in e-business adoption: Evidence from Australian transport and logistics companies, International Journal of Production Economics," vol. 146, pp. 300-312, November 2013.

[7] W.F. Li, "Analysis on Today's Global Economy and Trade," China Business Update, 2002, pp. 8-9.

[8] J.Z. Yang, and L.F. Yang, "Introduction to E-commerce(the second edition)," Publishing House of Electronic Industry. 2013.

[9] C.F. Jiao, and G.B. Gao, "International competitiveness of foreign trade e-commerce Strategy," Forum of World Economic \& Politics, 2006, pp. 31-36.

[10] J. Li, "Exploration of the rise and development of small cross-border e-commerce trade -- E-commerce and logistics service innovation in the post-crisis era," Practice in Foreign Economic Relations and Trade, 2012.

[11] T.Y. Kim, R. Dekker, and C. Heij, "The value of express delivery services for cross-border e-commerce in European Union markets," Econometric Institute Research Papers, 2016.

[12] S.Patida, and E. Suppawat, "The development of electronic commerce in Thailand for business which lead to the ASEAN Economic Community," Bangkok, Thailand: The 5th Rajamangala University of Technology National Conference, 2014.

[13] K. Zhang, L. Huang, "Research on Cross-border E-commerce platform selection in China small \& medium-sized enterprises," IEEE International Conference on Service Operations and Logistics, and Informatics. IEEE, 2015. 